formation of seed-orchards of Scots pine, Douglas fir, European larch and a few other species. Hybridization, followed by further selection, is being used to effect still further improvements.

The remainder of the second floor is occupied by the Pathology Section, which is concerned with the study and control of tree diseases. The work includes not only damage by fungi and bacteria, but also that due to non-living agencies, such as frost. At the moment, the control of Fomes annosus, the most serious cause of butt rot in conifers in Britain, is the major project of this Section. Other projects are top-dying of Norway spruces, a physiological disorder associated with increased exposure of the tree crown, and the testing of poplar and elm clones for resistance to bacterial canker and elm disease, respectively.

The Entomology Section, on the ground-floor, is engaged on investigations of a number of forest pests. It is normally concerned with the biology, including the occurrence of parasites, the forest status, which usually involves population sampling, and the control of each insect. In some cases, for example that of the pine looper moth (Bupalus piniarius), work has been particularly directed to finding the population. level at which the insect becomes a potential danger. In another case, that of the larch sawfly, work is directed to finding the effects of different populations and, therefore, of different degrees of defoliation, on tree growth.

The remainder of the ground-floor is occupied by the Photographic Section, which provides a common service to the rest of the Station, as well as to the Forestry Commission as a whole, taking most of the photographs required for illustration and record, and the slides necessary for lecturing purposes. The collection of more than 12,000 black-and-white photographs and nearly 7,000 colour slides is arranged numerically, but fully card-indexed on the International Forest Decimal Classification, so that photographs or slides on any particular subject can easily be located. The Section has produced several short films on forestry subjects.

The old building houses Administration, the Management Section, the Statistics Section, the Library, and a large room, which is used for meetings, conferences, lectures, etc.

The Management Section includes mensuration, which studies the growth of individual trees and of crops, and the methods of measuring them. It produces volume tables, yield tables, etc., for use in forest management. Management also includes the Census of Woodlands, and therefore has charge of all the data resulting from the census of all woodlands of 5 acres or more, carried out between 1947 and
1949 , and of the census of hedgerow and park timber carried out in 1951. Working from this basis, sampling surveys for general purposes and local surveys for special purposes will be used in the future to provide more up-to-date information. Now that the hitherto overriding need for a strategic reserve of timber has become less acute, it is obviously desirable that more attention should be given to the economic background of forestry in Britain. For this reason, the Management Section now includes an economist, who is studying the nature and volume of the demand for timber and relating these to the costs involved in raising it. The Management Section is also responsible for assisting the Forestry Commission field officers in the preparation of forest working plans.

The Statistics Section is again a common service to the whole Station. The statistician advises on the layout of all experiments, thus ensuring that the resultant data are suitable for computation. The long-term nature of, and the large areas involved in, many forest experiments make care over design of particular importance. Computation is now done on a 'Pegasus' electronic computer by arrangement with the Royal Aircraft Establishment at Farnborough. The Section also carries out research into the application of statistical methods to problems of forest research and management.

The Library is a small one, containing some 3,500 books; but it receives all the principal forestry periodicals and has a considerable collection of reprints, reports, etc. It also carries out documentation work, resulting in a large card index of literature references on British forestry and on aspects of forestry abroad which are of interest to British foresters. There is also a series of classified information files. All filing is arranged according to the International Forest Decimal Classification.

The Forestry Commission encourages more fundamental work on some of its problems by means of grants to universities and other institutions. This has enabled the Alice Holt Research Station to concentrate the efforts of its staff very largely on the more immediately practical aspects of forest research. Thus, despite the relatively small staff -36 research officers and 107 research foresters in the Research Branch as a whole-there is a considerable output of work, mostly published in Forestry Commission publications (Forest Records, Bulletins, etc.) or in forestry and other scientific journals. A summary of the work of the Station, with brief accounts of grantaided work at other institutions and with a number of short papers by the Research Station staff, is published annually as a Forestry Commission Report on Forest Research.

\title{
OBITUARIES
}

\section{Prof. J. G. Wood}

THe sudden death of Prof. J. G. Wood on December 8 last at the comparatively early age of fifty-nine has not only deprived the University of Adelaide of its senior professor but also has been a severe loss to biological work in Australia.

Joseph Garnett Wood was born at Mitcham, South Australia, on September 2, 1900, and educated at the University of Adelaide, where he obtained his first degres in the honours school of chemistry (1922).
Fortunately he had shown interest and ability in botany during his undergraduate course, and in 1923 he became a demonstrator in botany. A programme of work on the vegetation of arid South Australia was beginning and the assistance of a chemist was vital. The saltbush (Atriplex vesicaria) which covers huge plains in the arid parts of the State had been termed a halophytie on insufficient evidence. Wood collaborated in the ecological work, which showed that the soils were not saline, except for the scattered. salinas where Atriplex was absent. The plant had a 
high content of sodium chloride in the cells of its uncuticularized, tomentose leaves. Wood investigated the transpiration-rates of a number of trees and shrubs growing in the region and later showed that, in addition to having a low transpiration-rate, Atriplex was able to take up moisture through its leaves from saturated air. This work led to the award of an 1851 Exhibition scholarship, and Wood proceeded to Cambridge (Caius College) to read for a Ph.D. On his return to Adelaide in 1927 he was appointed lecturer, soon to be in charge of the Department. $\mathrm{He}$ was promoted to professor in 1935.

Work on the vegetation of arid South Australia had led to the generous donation to the University of an area of some 1,000 acres and small field laboratory at Koonamore, about 200 miles north of Adelaide in 1926. Wood collaborated in the work of the Koonamore Vegetation Reserve almost from the start. It is a tribute to his abiding interest in the arid flora that the Reserve and laboratory are still in regular use by the Adelaide Department for teaching and research.

Wood's contributions to botany fall under the heads of general ecology (his work on "The Vegetation of South Australia" (1937) has long been out of print), autecological work on arjd plants and nutritional studies. Recently (1957) he and one of his research students have shown that sodium chloride is an essential micronutrient for Atriplex vesicaria. The nutritional studies have dealt with nitrogen and sulphur metabolism and the role of such micronutrients as copper, zinc and molybdenum. These are essential for erop production over large areas of leached soils in Australia but are not needed in the same quantities by the native sclerophyllous plants.

Wood had considerable organizin akilities. The fine range of biologice] buildings at the University owes much to his planning. Possessed of an alert mind and known for his fairness and even temper, much of his time and energy of late years have been spent on committee work. He was a member of the Interim Council of the Australian National University during 1948-51 and a Council member during 1952-55. He served on the Advisory Committee of the Commonwealth Scientific and Industrial Research Organization during 1951-59 and was chairman of the Board of Standards, of the Australian Journals of Scientific Research, and chairman of the Board of Research Studies of his University at the time of his death.

His recreations were largely connected with his home and garden. He had a good knowledge of Australian contemporary art and he himself painted. In 1930 he married Joan Hazel, who, with their three daughters, survives him. His one-time teacher and colleague can only join his many other friends in deploring his sudden passing.

$$
\text { T. G. B. OsBorN }
$$

\section{Prof. W. R. Fearon}

Winltam Robert Fearon, professor of biochemistry in the University of Dublin, died on December 27,1959 , aged sixty-seven years. The only child of a Presbyterian clergyman who had died when his son was four years old, he entered Trinity College, Dublin, in 1911. It was an indication of the intellectual versatility which was to characterize his life that he found some difficulty in deciding whether to read English or science. In the event he read natural science, in which he graduated B.A. with a Senior Moderatorship in 1915, securing also a Foundation Scholarship in Experimental Science two years later. $\mathrm{He}$ entered the Medical School during this period, but became so intensely interested in physiology and biochemistry that he interrupted his medical studies in the fourth year to do research work in nutrition in London during the First World War. Following this, he was awarded an exhibition to Emmanuel College, Cambridge, where he became one of the devoted band which Frederick Gowland Hopkins gathered around himself in the University Bio. chemical Laboratory. On his return to Trinity College, Dublin, in 1921, he was elected to a fellow. silip and thus began a period of almost forty years during which he enhanced the reputation of the College with his researches, delighted his students with the brilliance of his lecturing and entertained his colleagues by his sparkling conversation on almost any topic.

His literary bent had found recognition while he was still a student in the award of the vice-chancellor's prize in English verse, the University Philosophical Society's Gold Medal for English composition and the editorship of the College miscellany, T.C.D., to which he was a frequent contributor. Throughout his career his clear, limpid style was to stamp every. thing he wrote whether scientific or otherwise. He was a master of the happy descriptive phrase which left an indelible impression. Always interested in motor-cars, he wrote of a visit to the Lancia showrooms in London during the early ' 30 's that he had been taken for a drive in a car "that was the size of a cottage and cost as much as a house".

His early work was concerned with the formation of urea from protein, in the course of which he began to exhibit that facility for developing colour reactions which was to lead to so many papers in the Biochemical Journal. He loved to demonstrate these reactions to his colleagues or to visitors, and he must have discovered far more than he ever published. His interest in nutrition persisted and found its most recent expression in a survey of the fluoride content of Irish drinking waters. It was typical of his alert mind that he began this work more than ten years ago, at a time when others were only commencing vaguely to realize the possible practical significance of fluoride intake in dental health. For about six years before his death he had been interested in the ureides obtained from autolysed yeast. An outstanding contribution was his book, "An Introduction to Biochemistry", first published in 1934 ; he was working on the fourth edition when he last became ill. It is remarkable in that it is at once "An Introduction" which unfolds the subject to the student systematically and with the utmost clarity, and a comprehensive review that can be consulted with profit by the more mature worker.

Notwithstanding a rather shy disposition, he had wide interests outside his laboratory and, indeed, outside College. In the '20's he was the friend and associate of the literary and artistic giants of the time in Dublin-W. B. Yeats, Jack Yeats, George Russell (AE), Lennox Robinson, Oliver St. John Gogarty. He held the honorary professorship of chemistry of the Royal Hibernian Academy. His play, "Parnell of Avondale", was a success when 